\title{
The Musicality of Campursari Music in the Islamic Ritual Context
}

\author{
Bambang Sunarto a,1,* \\ a Institut Seni Indonesian, Surakarta, Jl. Ki Hajar Dewantara No 19, Surakarta, 57126 Indonesia \\ 1 bsunarto432@gmail.com*; \\ * corresponding author
}

ARTICLE INFO

Article history

Received 2020-05-19

Revised 2020-06-10

Accepted 2020-06-20

Keywords

Music Syncretism

Ritual Event

Religious

Campursari

Adaptation

\section{ABSTRACT}

This article discusses campursari's music, which has an increasingly broad role, from profane to sacrilegious Islamic areas. Since its birth, this music serves as entertainment music. In the era of the 1990s and its peak in the 2000s, this music entered and interacted with the Islamic community. The entry of campursari music into the Islamic religious community is the embodiment of expectations and demands for environmental situations and conditions. Hopes and needs give birth to musical syncretism, which gives birth to adaptation strategies. Verstehen are appropriate methods for recognizing forms of adaptation and syncretism. The choice of the verstehen method is because this article does not merely highlight the problem of music, but also tries to understand the social actions of campursari musicians in serving the muslim community via campursari music. The choice of this approach is because musical adaptation stems from the idea that the birth of musicality has the support of a socially developed network of meanings. The benefit is to recognize the principles and rules of adaptive value and productive syncretism that occur behind music phenomena. The results of this study indicate that campursari's performance is sufficient to prove that campursari's musical musicality in the context of Islamic rituals is productive syncretism. Adaptation and syncretism are thus two methods and ways of building products, both of which must co-exist.

This is an open-access article under the CC-BY-SA license.

\section{Introduction}

In Central Java and its surrounding area, since the early 1990s has grown and developed a new musical genre called campursari music. It is a hybrid music, mixture genres of gamelan music with other musical genres, such as keroncong, dangdut, and pop. In essence, the creation of campursarimusic refers to a mixture of several different music genres today [1]. The collaboration between keroncong musicians from Radio Republik Indonesia (RRI) Semarang and gamelan musicians at URIL KODAM IV Diponegoro ${ }^{1}$ in post-1965 was the origin of the birth of this music genre [2]. There is an oral source that states that the delivery of campursari began with a collaboration between a group of gamelan musicians called Riris Raras Irama Surakarta led by Cipto Suwarso with a group of keroncong musicians named Radio Orkes Surakarta from RRI Surakarta in the 1970s. The collaboration took place to fill the live broadcast on Radio Republik Indonesia Surakarta. In the show, they jointly use their respective instruments to present and work on the song Kembang Kacang. They together play and perform this song using mixed devices, between gamelan and keroncong musical instruments [3]. Since the collaboration in the 1970s, the term campursari has become famous, to express the existence of music creations that combine elements of music, and produce musical productions that contain many of the essences of music [4]. Unfortunately, this event leaves no trace

\footnotetext{
${ }^{1}$ The nomenclature of KODAM IV Diponegoro in post 1965 (1970's) is KODAM VII Diponegoro. 
that can be used as data to explain its meaning. This program only has oral testimonies from people involved in gamelan music.

In the 1970s and 1990s, after collaborating on Kembang Kacang songs, people in Central Java still remembered the term campursari, and it is meaning, but this term was not very popular [5]. At that time, there was no creative activity that produced music like the phenomenon of campursari music creation. Although the broader community understands the meaning of the term of campursari, creativity related to the existence of campursari music did not grow. In 1990 until now, this music was overgrowing, and the wider community accepted it with joy. The development, the form of campursari music today, is different from the style of campursari in the 1970s. If in the 1970s, campursari music was a mixture of gamelan and keroncong instruments only, in the 1990s, campursari was a mixture of gamelan instruments with various electronic devices, drum sets, and Sundanese drums [6]. Since the 1990s, campursari music has become popular music that has adopted various musical techniques and aesthetic formats from multiple genres. Its position as popular music only exists for entertainment purposes. Wherever and whenever the presence of campursari music is as entertainment [7]. In the early 2000s, there was an exciting development of this music since increasing its function. Campursari's music, in the beginning, was only for entertainment, then it added features for ritual and pengajian ${ }^{2}$. Rituals are specific and religious activities to express attitudes symbolically. Spiritual beliefs and ethical principles guide ritual activities. The ritual implementation follows the rules that have become a habit in the community [8].

The increasing function of Campursari's Music for pengajian emphasizes a theory which states that adaptation is a manifestation of high awareness of the expectations and demands of environmental situations and conditions. The opinion of Fabrizio et al., adjustment is a method for finding comfortability [9]. Adaptation and shifting functions have an impact on changing musical context and tendencies. The musicality is present selectively in a variety of musical variations, so it fits the situation and conditions. This article will discuss the use of campursari music in a ritual to strengthen the religious atmosphere. The presence of campursari music in various ritual events and their application is a significant concern. Because, by revealing the existence of campursari music in various ritual events, it will be clear how musical adaptations occur in the context of religious culture.

\section{Method}

Disclosure of this problem uses an interpretive approach because musicality is a product of human thought in culture [10]. Therefore, understanding will be better and more accurate by using the verstehen method because the roots of musicality are practical and useful ideas [11]. That idea is the category element in music phenomena. The verstehen method is related to hermeneutics [12]. This method serves to help the discovery of the meaning of aspects related to the reality of music. Especially is the reality that is in the music category as an ideographic manifestation of the practical idea of music. In hermeneutics, types exist as texts to serve the context [13] [14], because the meaning of truth is the interaction between thoughts and their intentions. Interpretation is the primary manifestation of the existence of human ideas. Reading is not an instrument but an essence. Analytical approaches will complement interpretive methods that describe systemically related elements.

\section{Results and Discussion}

\subsection{Ritual Events}

In Javanese culture, there are several types of rituals that become a means of gathering events. The event is for individual or social purposes. Events for individual purposes include walimahan $^{3}$ or

\footnotetext{
2 The word "pengajian" comes from the word "aji," which means "valuable." The word "aji" gets the prefix "pe" and the suffix "an" so that when it becomes the word "pengajian," it has a new meaning, which is to make people become aji, become valuable. So, the term pengajian is the activity of religious lectures to bring many people learning about the provisions, rules, and principles of life-based on religious teachings so that they become valuable people or a pious person. ${ }^{3}$ Walimahan is a banquet held with respect to weddings.
} 
mantu, sunatan ${ }^{4}$ aqiqoh ceremonies. Events for social needs are pengajian ${ }^{5}$. The pengajian is an old culture that is still well embedded in the community.

\subsubsection{The Walimahan or Mantu}

Walimahan or walimatul 'urs is a party that celebrates a marriage. The ceremony of walimahan is after the marriage contract. There is a powerful law of fiqh that recommends and encourages the necessity of walimahan. Guests should be pious people, both rich and poor. Another term that similar to walimahan is mantu. Both are weddings but in a different cultural context. Walimahan is an Islamicbased cultural context, while mantu is an event based on the Javanese culture context. In walimahan, there are no rites or processions because it is only a matter of having fun, listening to music, and pengajian. The essence of walimahan is to be happy, to declare and announce to the public that the bride who was initially two people, each of whom is no longer single. Both have united in one marriage bond. In mantu, there is much activity of ceremony or procession. Mantu is one part of the entire wedding procession. This part is the fifth stage of marriage as the whole procession ${ }^{6}$.

\subsubsection{The Sunatan}

Term sunatan has similarities meaning with term khitanan. Both terms mean circumcision ${ }^{7}$ [15]. The execution of the sunatan ceremony occurs when boys approach puberty. In carrying out the sunatan or khitanan tradition, the Javanese have different customs. The practice of sunatan is customary with a Javanese cultural background, and there are also customs with a history in Islam [16]. In Javanese culture, the order of the ceremony is blakêtépé, setting up the tarub, siraman, grês, and ending with a celebration party. The party invites relatives, neighbors, and friends of parents of circumcised children. In Islam, the practice of circumcision is more straightforward. There are only setting up the tarub, grês, and celebration parties, which invite relatives, neighbors, and friends from the parents of circumcised children. The difference is that the ceremony of circumcision in Islamic culture includes speeches, music, and pêngajian. While circumcision in Javanese culture, there are only speeches and music, without pêngajian.

\subsubsection{The Aqiqoh}

Aqiqoh is a sacrifice of goats in Islamic law. The meaning of aqiqoh is an expression of gratitude to Allah God Almighty for babies born. The function of aqiqoh is as a redeemer, to release a newborn baby from the genie shack that accompanies all babies. Concretely, aqiqoh means slaughtering a goat on the seventh day of the birth of a baby. Goat meat after being cooked becomes a dish to eat together at a party. In the middle of the party, there is a ritual of cutting hair for newborns. The party which contains the hair cutting ritual is mostly called aqiqoh. After the ceremony of cutting hair, it is usually followed by a music presentation and often with religious lectures [17].

\subsection{Applied Campursari in Ritual Events}

In ceremony events (walimahan, sunatan, and aqiqoh), there is always (1) welcoming guest, (2) speeches, and (3) core needs of the event. The welcoming guest and statements at the walimahan, sunatan, and aqiqoh are alike. For Javanese, people call welcoming guests as pambagiharjã. For the speeches, what is different is the content. The procedures and ethics in a statement are the same. The core needs of walimahan, sunatan, and aqiqoh contain two agendas, namely ritual, and entertainment. The format of the ceremony between walimahan, sunatan, and aqiqoh is different because each has a specific form and their respective meanings. The aim of campursari music in those gathering events is to fulfill the needs in accompanying the schedule, (1) welcoming the guest, (2) speeches, and (3) core needs of the event. Therefore, there is music to accompany the welcoming guests, statements, and music for the core needs of the playing. Javanese people call the music for welcoming guests as

\footnotetext{
${ }^{4}$ Sunatan is circumcision receptions.

${ }^{5}$ There are also other social events such as the political campaign, the commemoration of state holidays, anniversary of a city, district, or province, and village ceremony in the frame of earth charity.

${ }^{6}$ The first is the procession of nêmbung, the second is the paningsêtan procession, the third is the kumbakarnan procession, the fourth is the pasang tarub procession, and the fifth is mantu which essence contains ceremonial processions. Each procession includes various ritual which have regular sequences.

${ }^{7}$ Circumcision is the removal of the foreskin from the penis. The procedure is the opening of the culub, removal of adhesion, and separation of the foreskin from the gland. After that, cut off the foreskin.
} 
Pambagiharjã music. This music creation is to meet the needs to express warm hospitality. The making of music for speeches is to animate every speech at the event. The nature of ritual music is to inspire the ceremonial atmosphere. Entertainment Music is anything type of music that gives enjoyment.

\subsubsection{Pambagiharjã Music}

Pambagiharja is an expression of respect that can use two ways. The first is the verbal way, uses words through speech. The second is symbolic. The remarks were speeches from various parties who had the opportunity to represent the invitees to express their respect for the guests. The deep respect in a verbal way is speeches containing words of thank, welcome, and apologies if there are things that are not pleasing. The deep connection in symbolism can use visual or auditive symbols. Expressing visual symbols is to enhance the venue. For the auditive logo, the expression is to use musical sounds. In Javanese gamelan music culture, the names of compositions in pambagiharja a music reflect the intentions, which symbolically mean humility, respect, and loyalty. In the Music of campursari, the name of arrangements lacks symbolic attention or meaning. The music of Pambagiharja an Campursari music, what is important is the expression of joy as a form of respect. The first notation of Figure 1 is an example of a nameless gêndhing, which is often for Pambagiharjã.

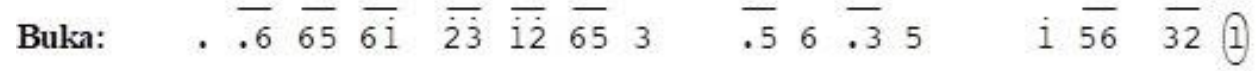

$$
\begin{aligned}
& \mathrm{E} \cdot \overline{.6} \overline{56} \mathrm{i} \cdot \overline{.5} \overline{6 \overline{32}} 1 \quad . \overline{.6} \overline{12} 3 \quad 6 \quad 5 \quad 3 \quad 2
\end{aligned}
$$

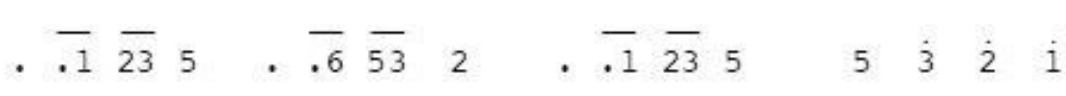

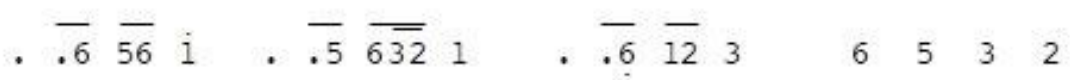

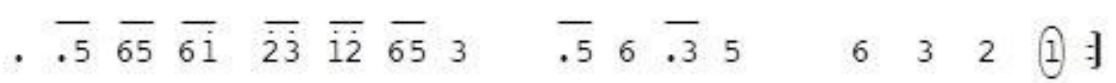

Fig. 1. Unnamed Gêndhing

How to play the composition written in Figure 1, the keyboard plays the buka part. All instruments follow after the keyboard plays reach the gong (the end) of buka. Keyboard, dêmung, and saron pênêrus play Figure 1, during the two saron barung play interlocking. Drumming style or kêndhangan uses traditional music phrases in the Sundanese form. The presentation of this song is instrumental, without accompanying vocal offerings. The musicians in the campursari group who presented this composition did not know the name and source of this composition. However, it is not an obstacle for them to show it. For them, names are not necessary. In campursari, to present something without tracing the source is not a big problem. Lack of clarity or lack of understanding, especially about the music they play, will not cause the severe. However, it does not mean that music has no source. They worked on compositions based on songs by Mang Koko (Koko Koswara) [18], entitled Karatagan Pahlawan, Laras Pélog, Pathêt Nêm, Irama Kêring. The song of Karatagan Pahlawan's notation is in other math or Figure 2.

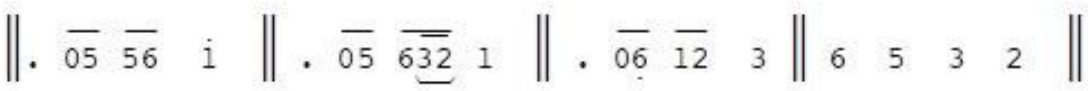

$$
\begin{aligned}
& \text { Teuhoncewang simoreang Tekadha Pah-la-wan bangsa } \\
& \text { Sina tri-a dana laga Bela bangsa jeung na-ga-ra }
\end{aligned}
$$

The following notation is on the next page. 


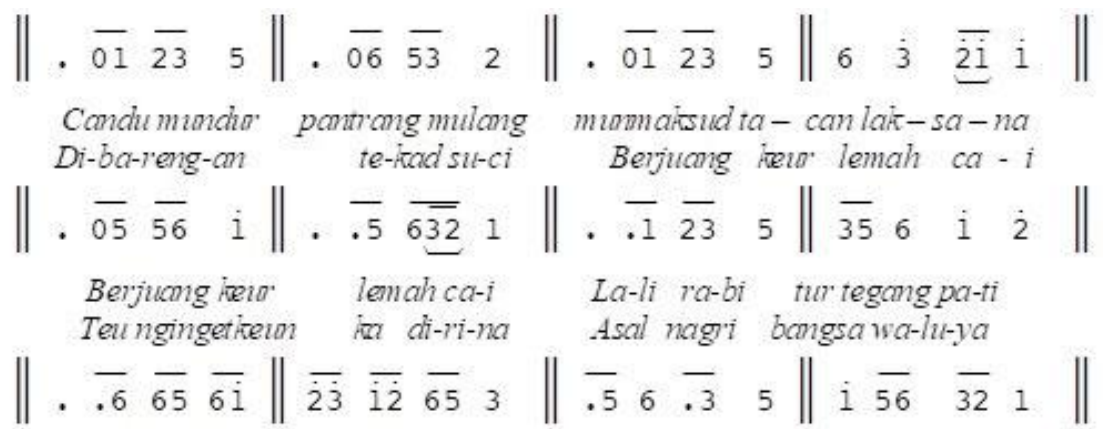

Tava basamentapanulangtarima I-khlas ri-dho keu korban merdika Kadar jem bar' raharja muluti wibava Gembleng tiguan pahiawan bangsa

(Koswara, 1989, pp. 38-39)

Fig. 2. Notation the Song of Karatagan Pahlawan, Laras Pélog, Pathêt Nêm, Irama Kêring

In campursari music, songs in first and second notations are usually present at the beginning of each event. The presentation is relatively long and repetitive. That repetition is intentional, to wait for the full guest chair. After many guest chairs occupied, gêndhing stopped, followed by next gêndhing. They then presented the second song, entitled Kidung Panulak. The Song of Kidung Panulak is in Figure 3.

Buka (equal with introduction):

$$
\begin{array}{lllll} 
& 1235 & .6 .1 & .6 .5 \\
1.6 & .5 .3 & .5 .3 & .2 .1
\end{array}
$$

Umpak (Equal with Interlude)

$$
\begin{aligned}
& \text { [.... } \quad \begin{array}{lllll}
1235 & 236 & \text {. } & \text { i } 65
\end{array} \\
& \text {... } \quad \begin{array}{lllllllllll:}
16 & 5 & 3 & 4 & 5 & 5 & 3 & 2 & 1
\end{array}
\end{aligned}
$$

Song (Part to acompany Gerongan)

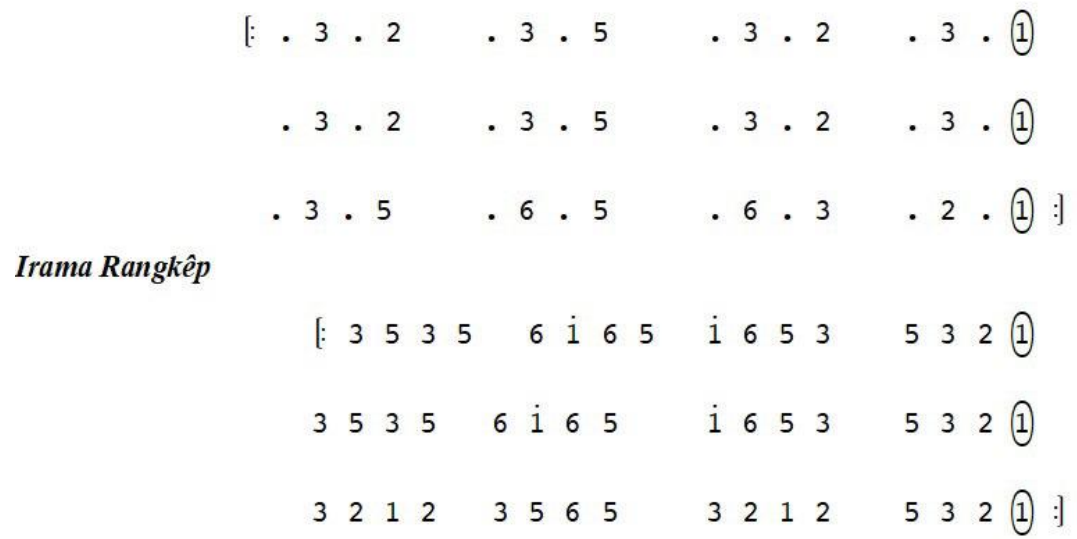

The following notation is on the next page. 


$$
\begin{aligned}
& \text { Gerongan Notation: }
\end{aligned}
$$

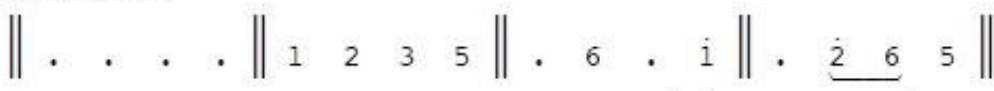

$$
\begin{aligned}
& \text { Gil-na-ne pa - mi-lak } \overline{i-k i}
\end{aligned}
$$

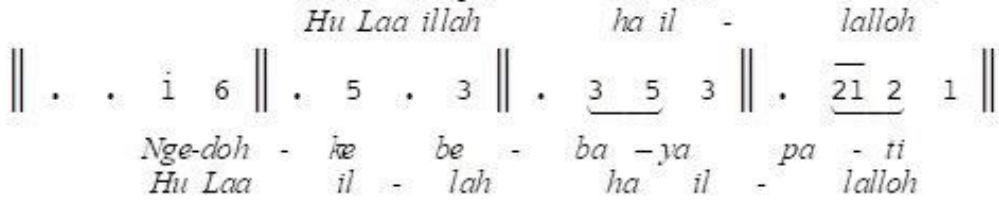

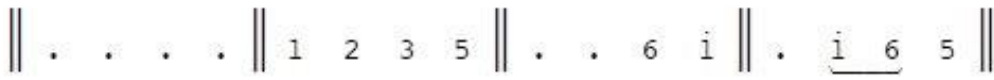

$$
\begin{aligned}
& \text { De-mit se-ton o-ra do-yan } \\
& \text { Hu Laa illah ha il - lal-loh }
\end{aligned}
$$

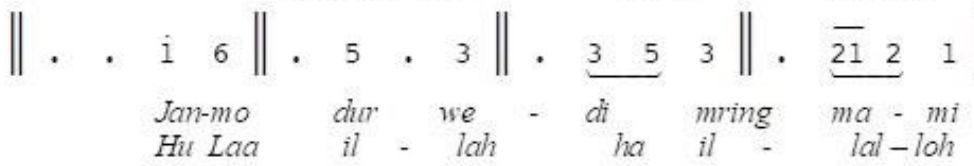

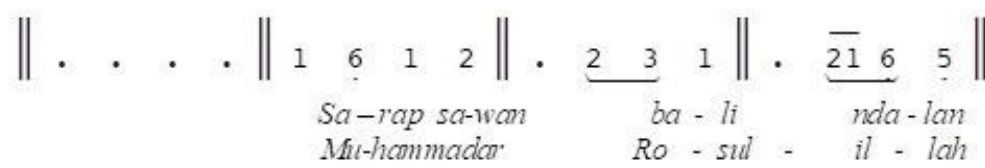

$$
\begin{aligned}
& \|\cdot \cdot \cdot \cdot\| \begin{array}{lllllllllll|l}
5 & 6 & 1 & 2
\end{array} \mid \cdot \begin{array}{lll}
\overline{21} & 2 & 1
\end{array} \| \\
& \text { Ko-lo ka-la - ne su - ming-iar } \\
& \text { Njeng Na-bi Na - ya - ka - ning rat }
\end{aligned}
$$

Fig. 3. Notation the Song of Kidung Panulak Laras Pélog, Pathêt Nêm

Gêndhing in Figure 3, although presented repeatedly, is usually not so long. The presentation uses complete instruments and vocals. The dominant device carrying the song's melody is the keyboard. The démung and saron pênêrus instruments present balungan melodies. The intended balungan melody is the melody in the interlude, in the song (the part to accompany the gerongan), and in the theme of irama rangkêp. Two of the saron barung usually play interlocking since the opening until suwuk or stop of the gêndhing. The serving of kendang uses the Sundanese style. After suwuk (stop), continued with the next gêndhing. The next gêndhing, as well as the first, is also unnamed. The presentation is instrumental and serves to accompany the opening speech as a greeting for audiences. The inaugural speech presentation is usually accompanied by gêndhing in Figure 4.

Buka : kendhang

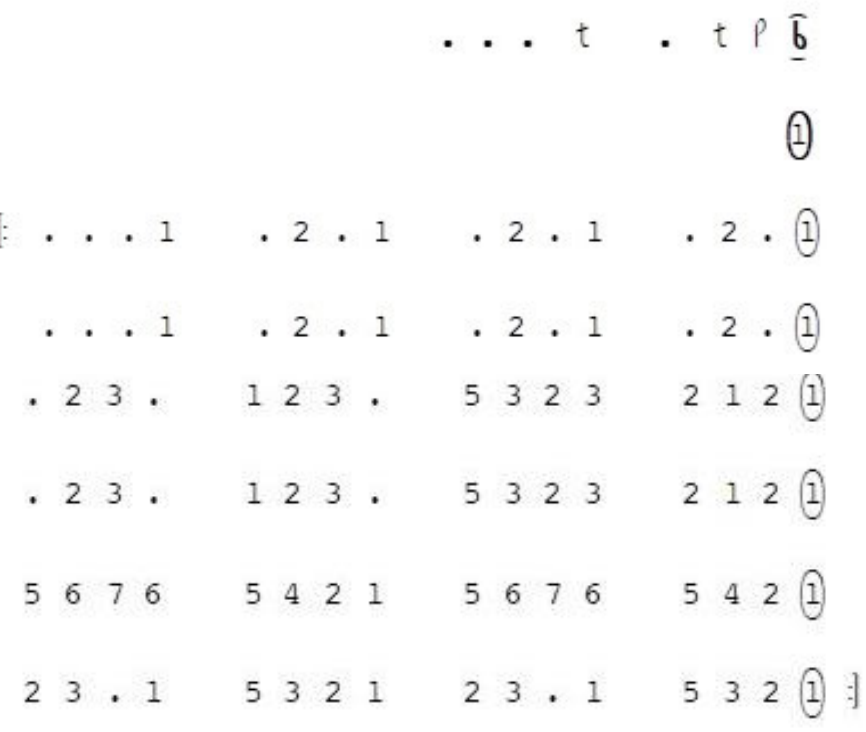

Fig. 4. Unnamed Gêndhing 
Along with the presentation of the unnamed gêndhing, in Figure 4, a master of ceremony made a speech to start the event. The intonation of the statement is similar to a poetry reading. The gêndhing above is a new incarnation or modification of the gêndhing of dênggung. The balungan notation of the gêndhing of dênggung is in Figure 5.

Buka:

$$
\begin{aligned}
& 5676 \quad 5421 \\
& 23 \cdot 1 \quad 5321 \quad 23 \cdot 1 \quad 532 \text { (1) } \\
& \text { [: . . } 1.5 \cdot 1 \quad \cdot 5 \cdot 1 \quad 5 \cdot 1 \\
& \text {. . } 1.5 \cdot 1 \cdot 5 \cdot 1 \cdot 5 \cdot 1 \\
& \text {. } 23 \cdot \quad 123 \cdot 5323 \quad 212 \text { (1) } \\
& .23 \cdot 123 \cdot 5323 \quad 212 \text { (1) } \\
& 5676 \quad 54421 \quad 5676 \quad 5421 \\
& 23 \cdot 1 \quad 53321 \quad 23 \cdot 1 \quad 532 \text { (1): }
\end{aligned}
$$

Fig. 5. Notation Dênggung Lancaran Laras Pélog, Pathêt Limo

By seeing the gêndhing of dênggung in full, it appears clear that the unnamed gêndhing in Figure 4 is essentially the gêndhing of dênggung. The composer has modified the first and second rows. So, the balungan arrangement of the gêndhing of dênggung seen in Figure 6.

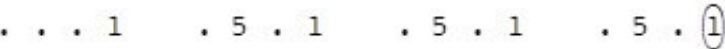

Fig. 6. The Balungan Arrangement of the Gêndhing of Dênggung

Whereas in the unnamed gêndhing seen in Figure 7.

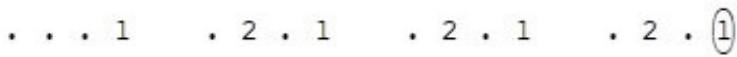

Fig. 7. The Unnamed Gêndhing

Meanwhile, the balungan arrangement in the third, fourth, fifth, and sixth row of the unnamed géndhing and the géndhing of dênggung is apparent that the two are entirely the same. That means the arrangement of the first and second rows of the géndhing of dênggung balungan has changed. The changes are in the first and second lines of the unnamed géndhing. To see changes see in Figure 4. After the opening speech ended, the unnamed géndhing then stopped. Next, they sang the song of Sholawat Badar in the Kyai Kanjeng version. The notation of Sholawat Badar in the Kyai Kanjeng version, as in Figure 8, in the pelog scale. 


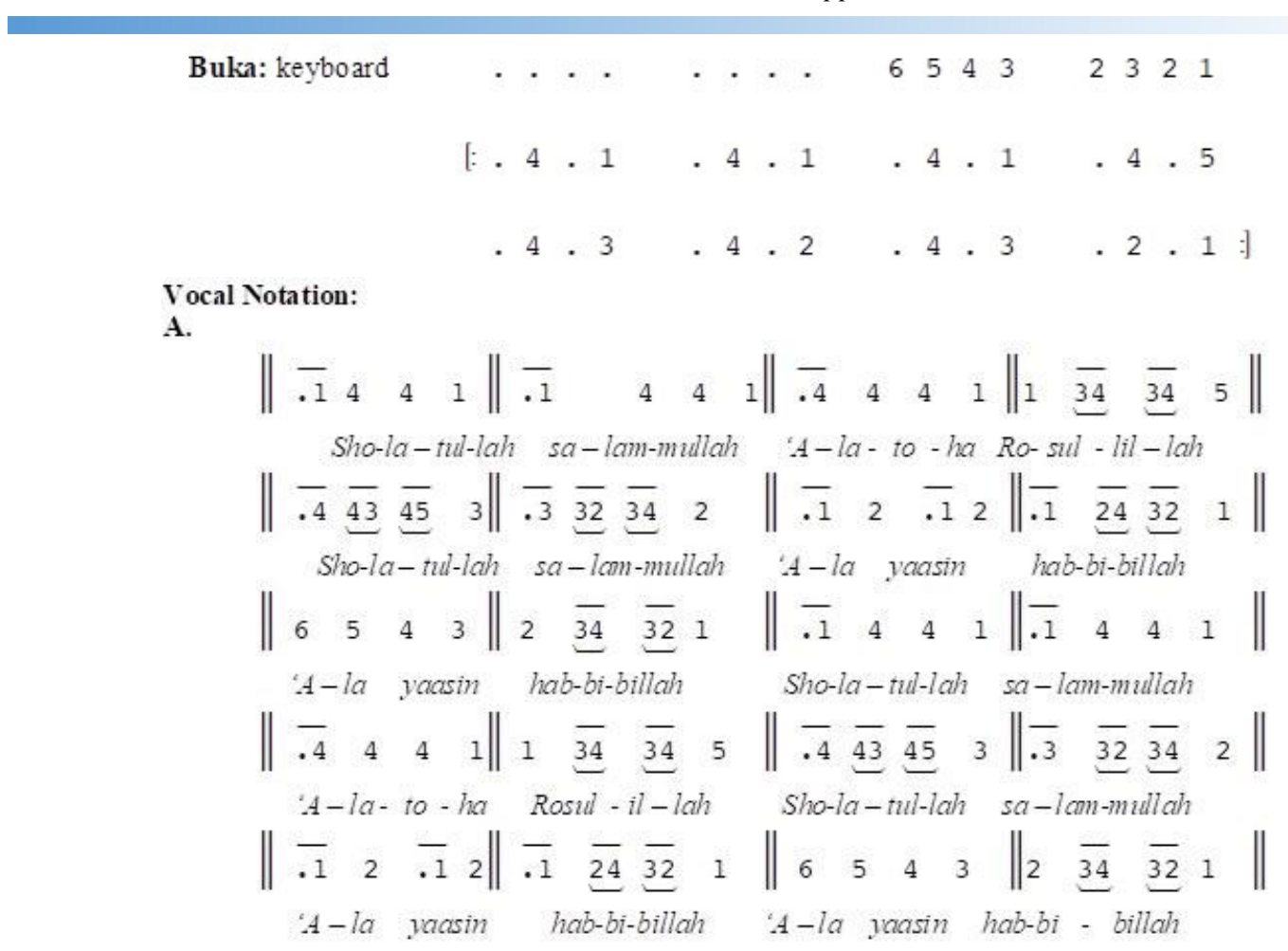

B.

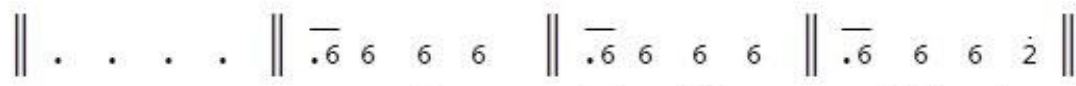

$$
\begin{aligned}
& \text { Tawa-sal-na bi bis-millah Wa bil ha-dii }
\end{aligned}
$$

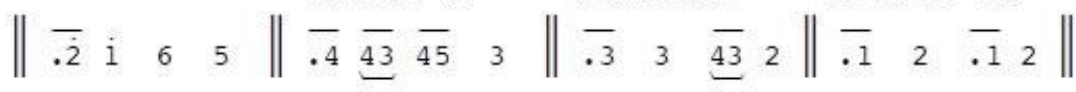

$$
\begin{aligned}
& \text { Ro-sul-lil-lah Wakullimija hiddil-lillah Bi ah-lil ba }
\end{aligned}
$$

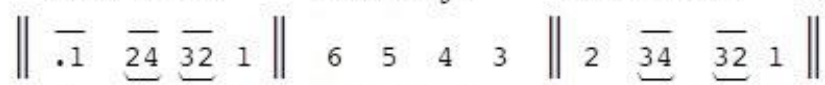

$$
\begin{aligned}
& \text { dri YaaAllah Bi ah-lil ba - abi Yaa Allah }
\end{aligned}
$$

Fig. 8. Notation The Song of Sholawat Badar in Kyai Kanjeng Version

The song Sholawat Badar is a marker of the end of the pambagiharja a session. For the next event, enter the speech session.

\subsubsection{The Speech Music}

Every gathering event in Javanese society, there are always speeches. In one event usually consists of several speeches. The number of people who give speeches depends on the will of shohibbul hajat ${ }^{8}$. If there is no speech from the party considered necessary by shohibul hajat, there is at least one speech. This speech is always in various gathering events. This speech is welcome, and thanks to the attendees from the shohibbul hajat. This speech is called pambagiharja speech. This speech is usually done by others to represent shohibbul hajat. Campursari musicians always accompany speeches with certain gêndhing. If there is only one speech representing shohibul hajat, the musician presents the music to accompany the person whose speech goes to the pulpit as a tribute. Likewise, when the speech was over, the person carrying out the speech returned to his seat, also respected with musical accompaniment. The music to accompany the person giving a speech to the pulpit is gêndhing Kêbogiro. Skeleton of the gêndhing Kêbogiro is in Figure 9.

\footnotetext{
${ }^{8}$ Shohibul hajat is a person who has the will to hold a gathering for the certain purposes.
} 
Bukã:

$$
\begin{aligned}
& \text {... } \quad 456 \text { i } \quad 4 \quad 626 \text { i } 6566 \text { (4) }
\end{aligned}
$$

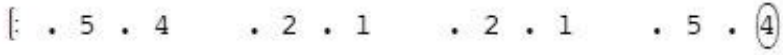

$$
\begin{aligned}
& \cdot 5 \cdot 4 \quad \cdot 2 \cdot 1 \quad \cdot 2 \cdot 1 \quad \cdot 5 \cdot 4 \\
& .5 \cdot 4 \quad 5 \cdot 6 \quad .5 \cdot 6 \quad .5 \cdot 4 \\
& .5 .4 \quad 5.6 \quad .5 .6 \quad 5.4 \\
& \cdot 6 \cdot 5 \cdot 2 \cdot 1 \quad \cdot 2 \cdot 1 \quad 5 \cdot 5 \cdot 5 w k
\end{aligned}
$$

\begin{tabular}{|c|c|c|c|c|c|c|c|c|c|c|c|}
\hline Bukã & . & . . & . & 56 & 67 & $\dot{2}$ & 73 & & $\dot{2}$ & 76 & 76 \\
\hline 1: & . & 6 . & 5 & . 3 & 3 . & 2 & . 3 & . & 2 & . 6 & . \\
\hline & . 6 & 6. & 5 & . & 3 . & 2 & . 3 & & 2 & . 6 & . \\
\hline & . 6 & 6. & 5 & . & 6. & 7 & . 6 & • & 7 & . 6 & . \\
\hline & - 6 & 5 & 5 & . 6 & 6 . & 7 & . 6 & & 7 & . 6 & 5 \\
\hline & . 7 & $7 \cdot 6$ & 6 & . 3 & 3. & 2 & . 3 & 3 & . 2 & . 6 & 5 \\
\hline
\end{tabular}

Fig. 9. Notation Kêbogiro Laras Pélog Pathêt Lima

The gêndhing of Kêbogiro, laras pélog pathêt lima in Figure 6 is a modification of the gêndhing of Kebogiro, laras pélog pathêt barang in Figure 10.

Fig. 10. Notation Kêbogiro Laras Pélog Pathêt Barang

Another gêndhing that serves to accompany individuals who make speeches is Lancaran Udan Mas, laras pélog Pathet lima. The skeleton of the gêndhing is in Figure 11.

Bukã

$$
\begin{aligned}
& \text {. } \begin{array}{rrrrrrrrrrrr}
6 & 6 & 4 & 5 & 6 & \text { i } & \text { i } 6 & 5 & 4 & 5 & 6 & 5
\end{array} \\
& {\left[\begin{array}{llllllllllllllllll}
5 & 5 & 4 & 2 & 1 & 5 & 4 & 2 & 1 & \text {. } & 2 & 1 & 2 & 5 & 4 & 2
\end{array}\right. \text { (1) }} \\
& \begin{array}{lllllllllllllllll}
5 & 4 & 2 & 1 & 5 & 4 & 2 & 1 & . & 2 & 1 & 2 & 5 & 4 & 2 & 1
\end{array} \\
& 6456 \quad 456 \text { i } \quad .654 \quad 6 \quad 565 \text { (4) }
\end{aligned}
$$

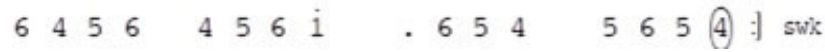

Fig. 11. Udan Mas, Lancaran Laras Pélog Pathet Lima

The gêndhing of Udan Mas, laras pélog pathêt lima in Figure 9 is a modification of the gêndhing of Udan Mas, laras pélog pathêt barang in Figure 12. 
Bukã:

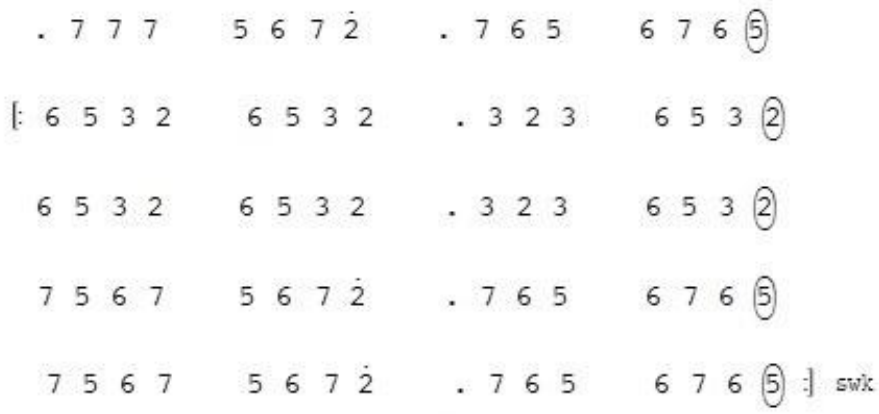

Fig. 12. Notasion Udan Mas, Lancaran Laras Pélog Pathet Barang

\subsubsection{The Ritual Music}

Rituals are activities that traditionally relate to rites and ceremonies. Ritual means a symbol of social and religious status. So, rituality is a reflection of the relative position of the person carrying out the ritual, related to beliefs, abilities, and lifestyle. Ritual is a manifestation of the principle of a phenomenon related to the orientation of beliefs and religious teachings so that the attitude of religious adherents is concerned with occult matters [19]. In walimahan, there are three kinds of processions. First, the procession is the appearance of the bride's journey to the altar. Second, the procession is the arrival of the groom to the bride's family home. The third, the procession is têmu pêngantin or panggih. To create a solemn atmosphere of three types of processions, musicians present two characters of different musical compositions. The sholawat poem and its music, entitled Tola'al Badru, accompanied the first and second processions. The notation of Tola'al Badru as in Figure 13.

A.

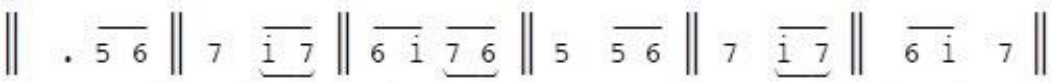

$$
\begin{aligned}
& \text { To-la' al ba - dur 'a-lai-na Mnsta-nii yat - til wadaa' } \\
& \text { A-yu-haal mab-'uutsu fii - na Ji'-ta-bil con - nil mutho } \\
& \|. \overline{56}\| 7 \underline{\overline{i 7}}\|\overline{6 i} \underline{76}\| 5 \overline{56}\|7 \overline{\underline{65}}\| \overline{36} \quad 5 \| \\
& \text { Wa-ja-ba syu - kou' } a \text {-lat - na Maada - 'aa lil - laa-hi daa' } \\
& \text { An-ta ghou-tsu - na ja-mii' an Yaamu-jaconmal a-thi-baa' }
\end{aligned}
$$

B.

$$
\begin{aligned}
& \|. \overline{66}\| 6 \quad \overline{60}\|\overline{66} \quad 6 \quad\| 2 \overline{56}\|7 \overline{\overline{i 7}}\| \overline{6 i} \quad 7 \| \\
& \text { Kim-tsa-fi - an yaa ha-bii - bii Yaulmahats-riw waj-ti-maa' }
\end{aligned}
$$

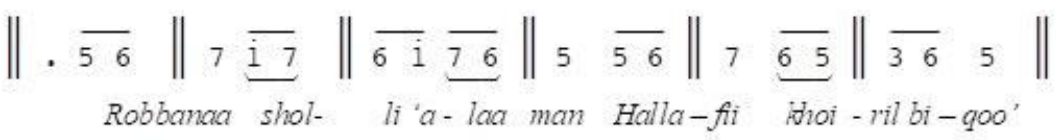

C.

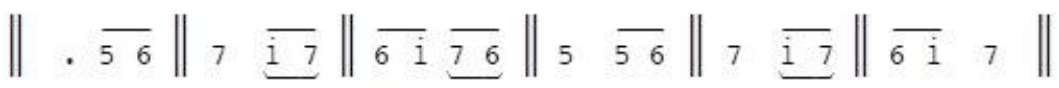

$$
\begin{aligned}
& \text { Fashbi-liis sit - tro 'a-lai - na Waify-naa syar-roon-ni-zaa' } \\
& \text { Washo -la - tullah-hi da-waa-maa Lil na-bii tsas-sii ni-qoo' }
\end{aligned}
$$

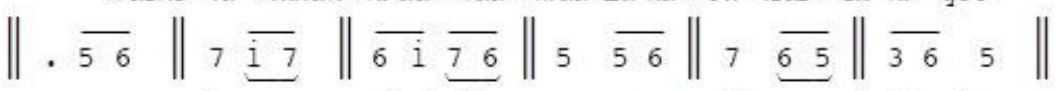

$$
\begin{aligned}
& \text { Wa-a-ghits naa - fii bal-laa - taa Yaa mu-ghii tsan-kulla-daa' } \\
& \text { Wa-ka-dhaa.A - li wa-shoh-baa Maasa'aa lil-laa - hi-saa' }
\end{aligned}
$$

Fig. 13. Notation Tola'al Badru

Tola'al Badru also functions as an accompanist to the aqiqoh ceremony, especially in the procession of hair cutting. In this procession, parents and elders cut the baby's hair respected in aqiqoh. To accompany the procession of têmu pêngantin or panggih, musicians go along with music 
that is under the nature of Islamic culture, which presents the song of Sholawat with Asyoqol text. The notation of Sholawat in Asyoqol text as in Figure 14.

$$
\begin{aligned}
& \overline{55}\|\underbrace{\overline{5 \overline{65}}} \overline{45}\| \overline{\overline{.7}} \underbrace{\overline{6765}}\left\|_{4} \quad \overline{76}\right\| \underbrace{5 \overline{\overline{.4}}} \overline{\overline{323}} . \| \\
& \mathrm{YaaNa} \text { - bi salon 'a - lai - ka YaaRo-sul salam } \\
& \text { Qol bachu a - lai - na faibl-ta - fat minhul }
\end{aligned}
$$

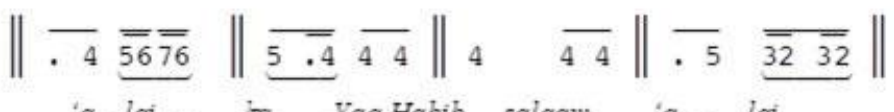

$$
\begin{aligned}
& \text { a-lai - la YaaHabib salaam a-lat } \\
& \text { bu-dut - nu mitslahus- nikmaa ro- at } \\
& \text { I }
\end{aligned}
$$

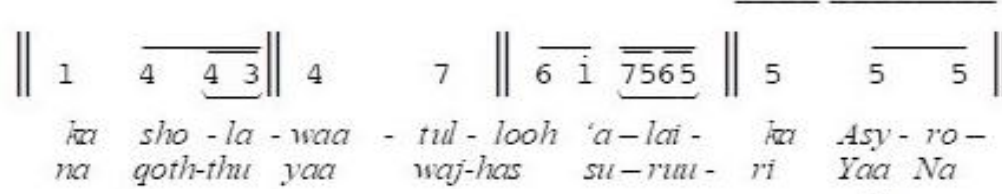

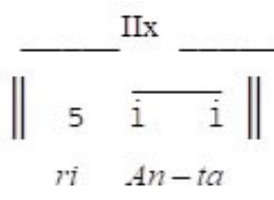

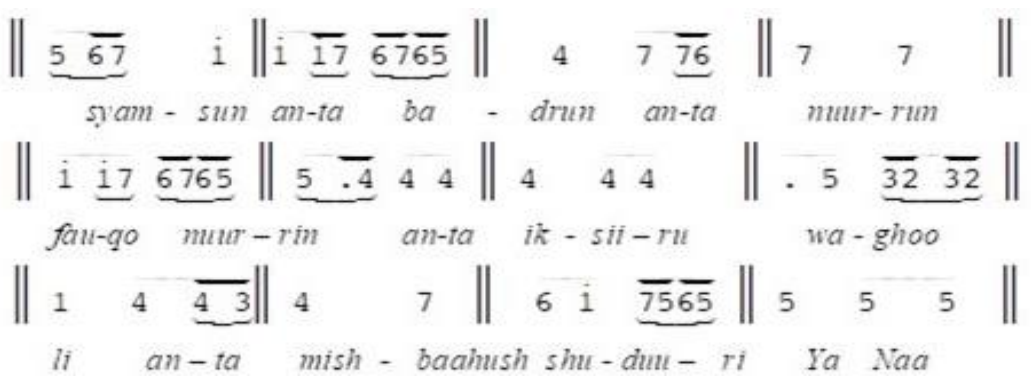

Fig. 14. Sholawat in Asyoqol

\subsubsection{The Entertainment Music}

There is a new phenomenon that shows that ritual activities still set aside opportunities for fun. The presentation of campursari music in ritual activities is a necessity because the nature of campursari music is entertainment music. Campursari music lovers are diverse. So, entertainment music in campursari is undoubtedly also a variety of genres that are the basis. There are at least four types of music. First is music with gêndhing type, second is music with popular song type, third is folk song type, and fourth is pesantren songs type.

\subsubsection{Music with Gêndhing Type}

Gêndhing is a musical composition, the embodiment of gamelan music culture in Javanese, Sundanese, and Balinese gamelan. Gamelan musician's interpretation of the skeleton of gêndhing forms the composition of the gêndhing. In practice, musicians attach melodic patterns or musical phrases under the framework of gêndhing. The melodic pattern or musical phrase has a function as a vocabulary to interpret and apply the results of interpretation. Musical sounds as a result of the whole interpretation performance by gamelan musicians are gêndhing. The skeleton or framework of gêndhing is an abstraction of musical depth felt by gamelan musicians [20]. The skeleton of gêndhing is a melodic arrangement that is abstract, raw ideas, and not entirely musical. Gamelan musicians turn fresh ideas that are not yet wholly musical into musical expressions that cause good musical sounds. Gamelan musicians then perform artistic acts, expressing themselves by interpreting the skeleton of gêndhing.

The application of interpretation uses the treatment instrument to the skeleton of gêndhing. Cultivation uses instruments to form musical constructs that involve (1) treatment instruments, (2) 
structural instruments, and (3) skeleton instruments. One example of music in gêndhing type is the presentation of gêndhing "Niyat" begins with the singing of Bãwã Sêkar Mocopat Pangkur 1. The notation of Bãwã Sêkar Mocopat Pangkur 1 next to gêndhing Niyat, Laras Sléndro, Pathêt Sanga as in Figure 15. The presentation of Bãwã Sêkar Mocopat Pangkur is like the presentation of plainsong in gerongan chant. In gerongan chant, a soloist sings it to a non-metric rhythm. The difference is, gerongan chant often functions to sing psalms with responsorial and antiphonal methods. In the responsorial method, solo singers sing a series of verses, each solo singer finishes singing a verse, then followed by a response from the choir with the same melody and rhythm as the singing of the solo singer. In the antiphonal method, soloists and choirs take turns singing verses, while in Bãwa Sêkar Mocopat Pangkur soloist singing independently without a choir to follow.

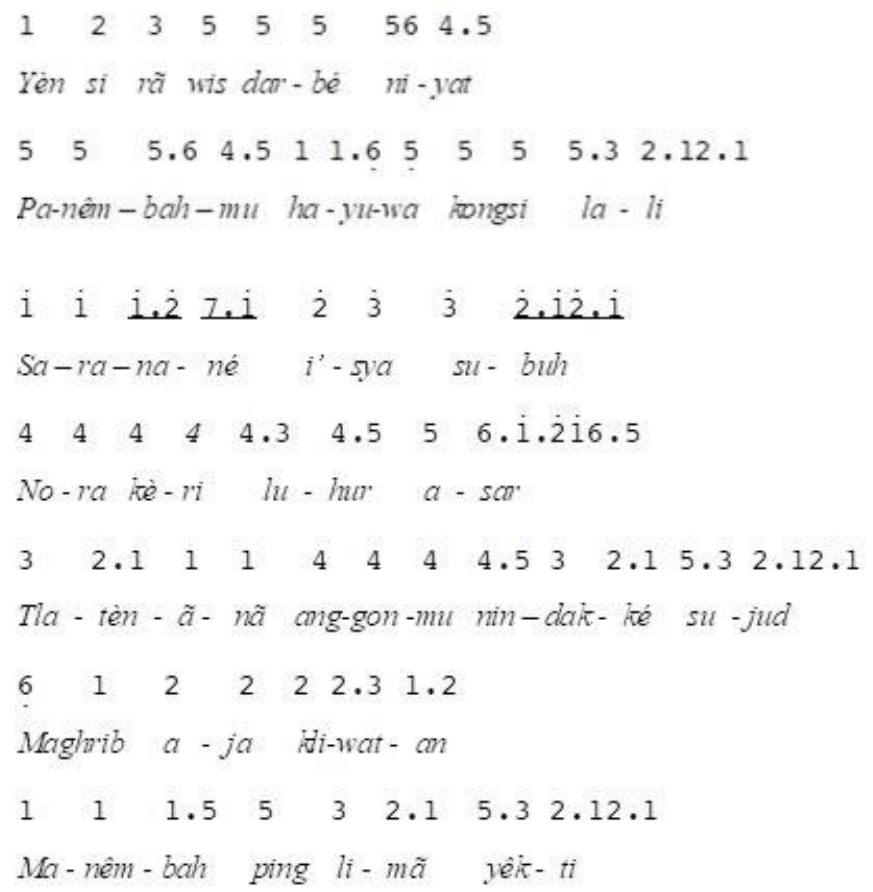

Skeleton Notation:

$$
\begin{aligned}
& \text { E } . \begin{array}{llllllllll} 
& 21 & 6535 & 5 & 5 & 53
\end{array} \\
& \text {. } 211653 \hat{5} \quad . .51 \quad 2121 \\
& \text {. . } 16 \quad 565 \hat{3} \quad \text {. . } 155152 \text { (1) }
\end{aligned}
$$

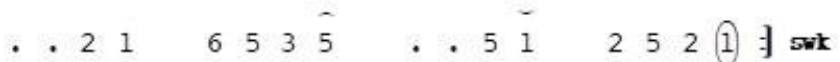

\section{Gerongan Notation:}

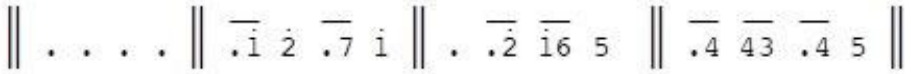

$$
\begin{aligned}
& \text { No-ra la-li pannzwué mring hywang widi }
\end{aligned}
$$

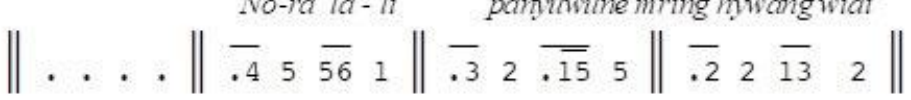

$$
\begin{aligned}
& \text { Kùdusiê-gêp panyunumée }
\end{aligned}
$$

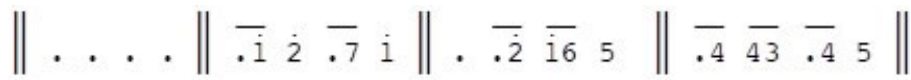

$$
\begin{aligned}
& \text { Dimèn têntrêm uripéing a-lam donya }
\end{aligned}
$$




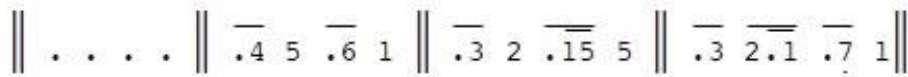

$$
\begin{aligned}
& \text { Sholat fardu ka-pingli-ma ndang tindak-na }
\end{aligned}
$$

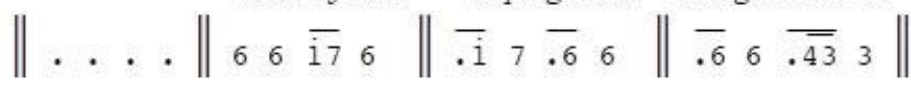

$$
\begin{aligned}
& \text { Amê-muji pêr-lunadyan ta-ngi tu-ru }
\end{aligned}
$$

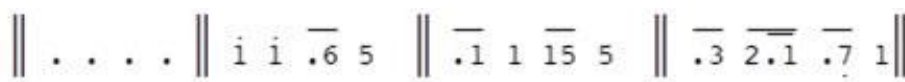

$$
\begin{aligned}
& \text { Da-tanlè-nã ka-rébènmang- gihra-ha-yu }
\end{aligned}
$$

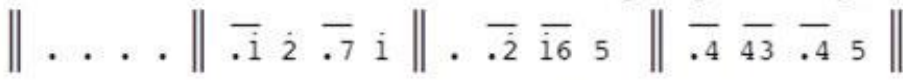

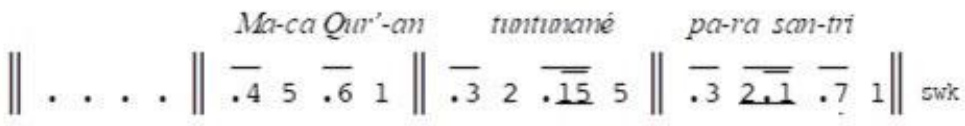

$$
\begin{aligned}
& \text { Man-fa-at-é bi-sa ngè-doh - hèn bi-la-hi }
\end{aligned}
$$

Fig. 15. Bãwã Sêkar Mocopat Pangkur next to Niyat, Laras Sléndro, Pathêt Sanga

Above gêndhing is a modification of the gêndhing of Ngimpi, laras slendro pathet sanga. Bãwã Sêkar Mocopat Pangkur 1 also a modification of the tembang Bãwã Sêkar Mocopat Pangkur 2. Observation of both Bãwã Sêkar Mocopat Pangkur shows that the number of lines is no different at all. Observation to the gêndhing of Niyat, laras sléndro, pathêt sanga, compared with the gêndhing of Ngimpi, laras slendro pathet sanga also same. The notation and composition show that the melody construct is the same. The layout of the structural instruments is also the same. The difference that stands out is in the poetic text. The text of Bãwã Sêkar Mocopat Pangkur 1 and the text on gêndhing Niyat, laras slendro pathet sanga is a solicitation or religious appeal in straightforward language. Text on Bãwã Sêkar Mocopat Pangkur 2 and the gêndhing of Ngimpi, laras slendro pathet is a romantic expression with a sophisticated and beautiful figurative language that reflects works of music with quite high literary quality. The notation of Bãwã Sêkar Mocopat Pangkur 2 next to the gêndhing of Ngimpi, Laras Sléndro, Pathêt Sanga as in Figure 16.

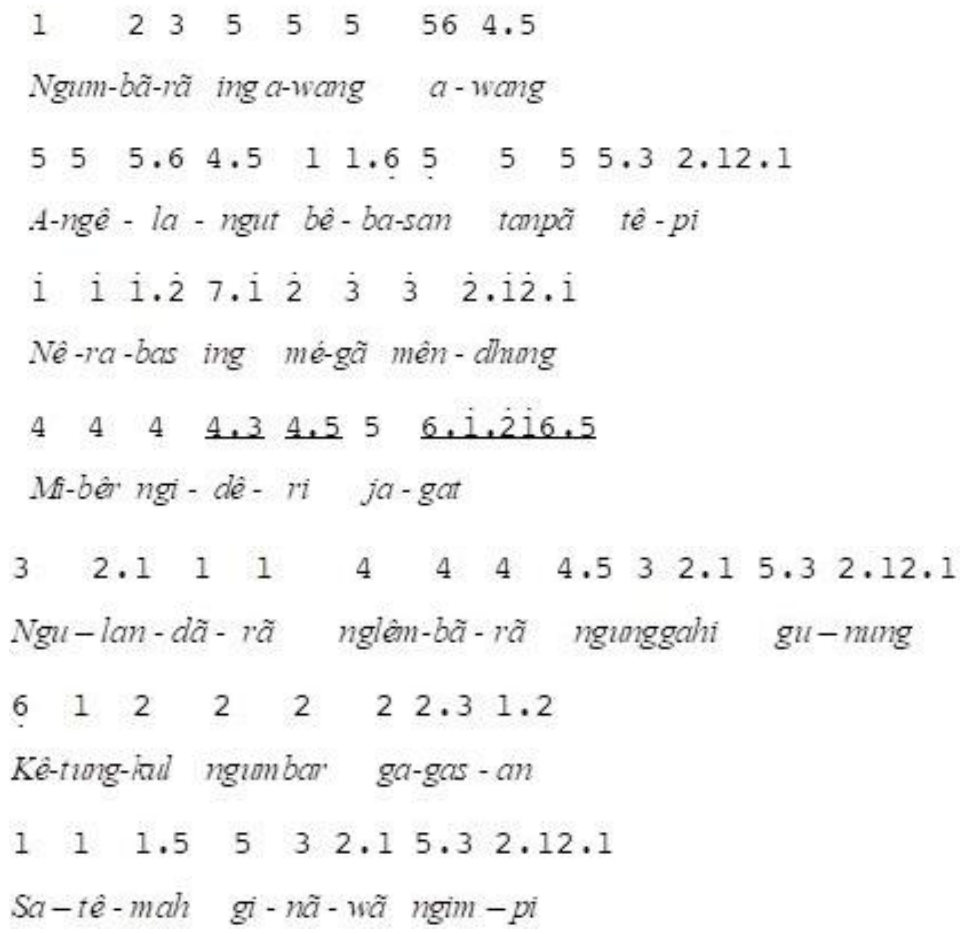


Skeleton Notation:

$$
\begin{aligned}
& \text { E . . . } 21 \quad 6535 \quad . .5156532 \\
& \begin{array}{rlllllllllll}
2 & 2 & 6 & 5 & 3 & 5 & 2 & 1 & 2 & 1
\end{array} \\
& \text {. . } 16 \quad 565 \hat{3} \quad \text {. . } 1551520 \\
& \left.\begin{array}{lllllllllll}
.1 & 2 & 5 & 5 & 5 & 2 & 5 & 2 & 1
\end{array}\right] \text { sik }
\end{aligned}
$$

Gerongan Notation:

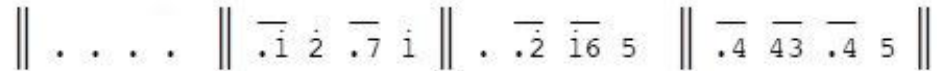

$$
\begin{aligned}
& \text { Sri-pat sri-pit lèmbèhané mér rakhê-simpir }
\end{aligned}
$$

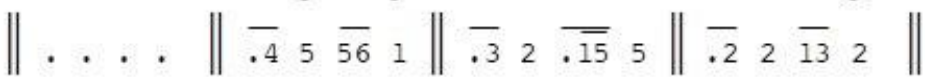

$$
\begin{aligned}
& \text { Gandhêslu-wês wi-ra-ga-né ang-lan-lan-i }
\end{aligned}
$$

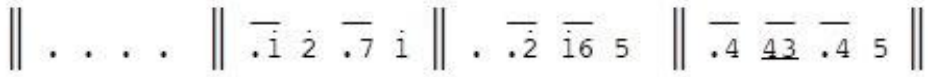

$$
\begin{aligned}
& \text { Sè-chêt singsêt bêsus } a-n g a-d i b u-s \tilde{a}-n \tilde{a}
\end{aligned}
$$

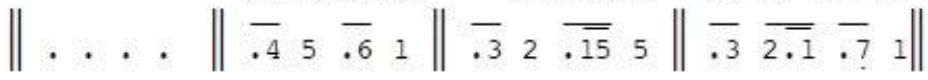

$$
\begin{aligned}
& \text { Dasar a-yu maki-sihkê-mã tanka-ci-wã }
\end{aligned}
$$

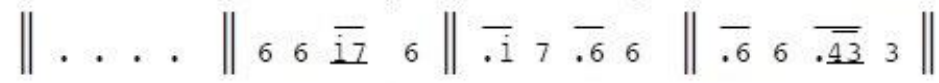

$$
\begin{aligned}
& \text { Takca-kêt-i a-duhmèsêm sêpèt madu }
\end{aligned}
$$

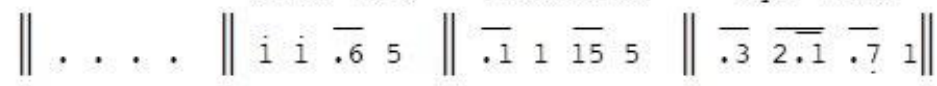

$$
\begin{aligned}
& \text { O-ra srãntã takgandhèng ma-lah gu-mu-yu }
\end{aligned}
$$

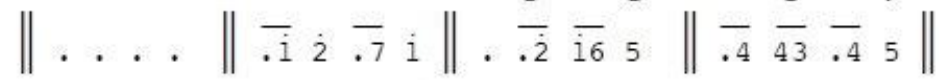

$$
\begin{aligned}
& \text { Ka-ton bungah kênyã kang pin - dhã hap-sa-7i }
\end{aligned}
$$

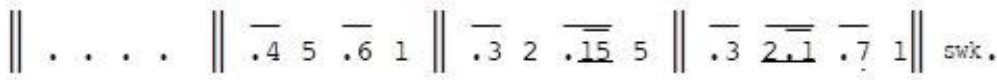

$$
\begin{aligned}
& \text { Kll-ci-wa-né kabèh ma-u comangngimpi }
\end{aligned}
$$

Fig. 16. Bãwã Sêkar Mocopat Pangkur 2 next to Ngimpi, Laras Slendro Pathet Sanga

\subsubsection{Music with Popular Song Type}

Popular songs are a well-known song in the community as part of mass culture [21]. Popular songs have the characteristic of being liked by the public. The people often imitated this kind of song because it has a simple grammatical structure. The characteristics of this type of song are unity with (1) publicity in the electronic mass media, cassettes, and commercial CDs or VCDs, (2) creation based on commercial considerations, (3) poems tend to lead to basic emotions, and (4) simple melodic phrases. The diatonic scale is the basis for making popular songs. Cultivation and presentation using a western music system. An easily recognizable feature is the cultivation of songs in a homophonic manner, namely the cultivation of a chord-based system so that the harmony system plays an essential role in shaping musical compositions [22]. An example of this type is the song of Ya Nabi Salam. This song is a modification of the song of Cinta Tak Terpisahkani by Dikin. The notation of Cinta Tak Terpisahkani as in Figure 17. 


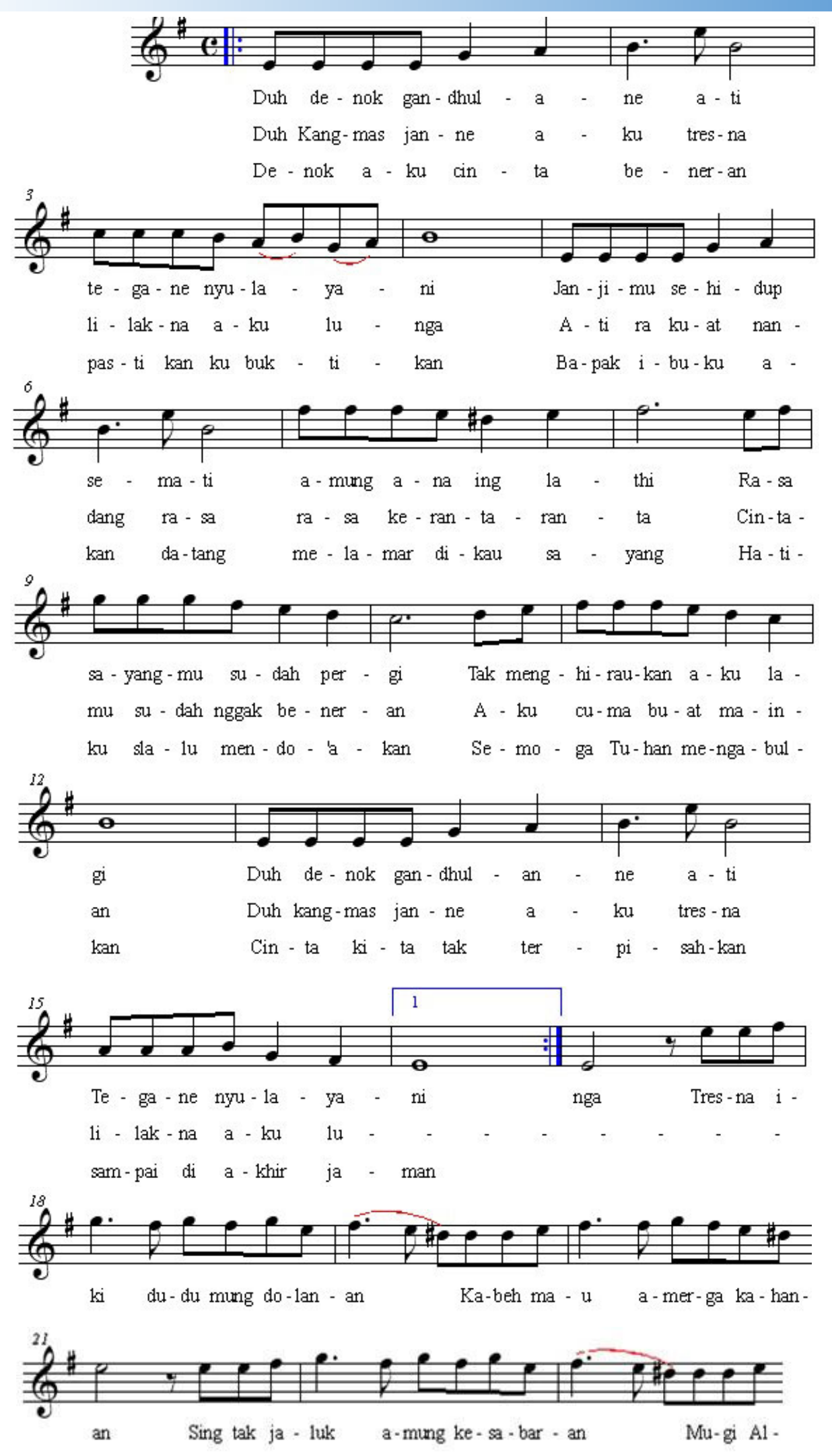

The following notation is on the next page. 

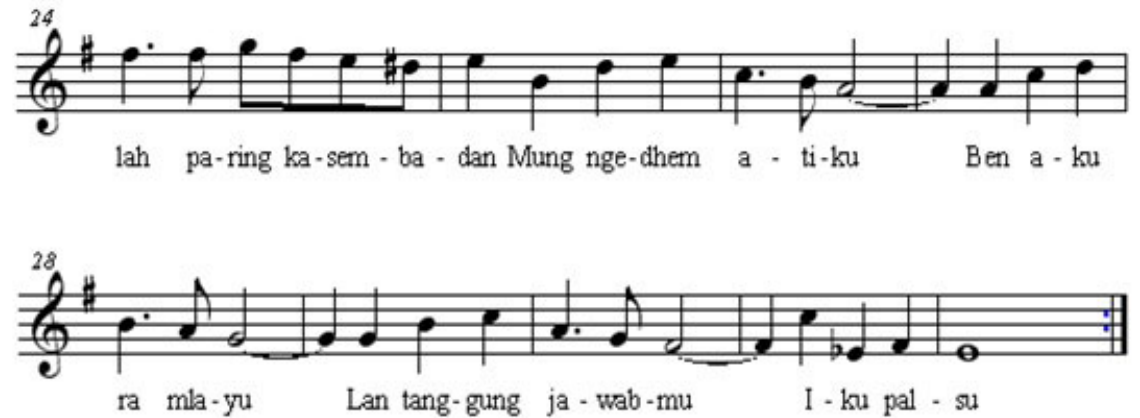

Fig. 17. Notation Cinta Tak Terpisahkan by Dikin

Campursari musicians consider that the song Cinta Tak Terpisahkan is very entertaining. They believe that presenting the song of Cinta Tak Terpisahkan in the context of Islamic rituals is suitable. Presenting this song in the context of Islamic rituals for entertainment purposes is necessary. However, the poetry of the song for entertainment music must be under the context. The song Cinta Tak Terpisahkan does not contain messages that nuanced Islamic spirituality. The song is expressions containing basic human emotions with an intensity that does not touch depth. For that reason, there needs to be an adjustment to the Cinta Tak Terpisahkan song with Islamic nuances. The way to make adjustments is to change the contents of poetry, from expressions of love of two opposite sex to religious expressions. The religious impression of Islam is evident in Arabic poetry. The lyrics are like songs that grow and develop in pesantren ${ }^{9}$. Most Muslims often hear this poem and meet in various places, because of the nature of expression that is common to Muslims. The poem is already in the book of Maj'mu Attulmawalid [23]. The notation of Cinta Tak Terpisahkani as in Figure 18.

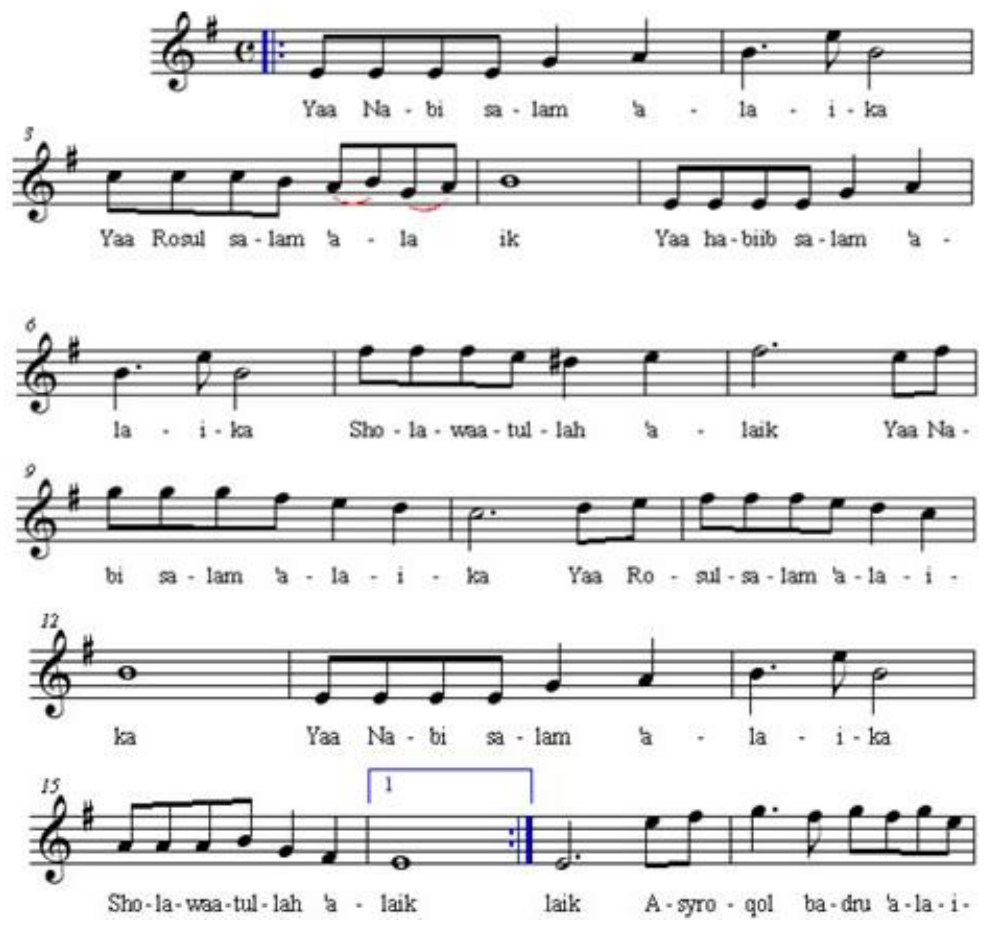

The following notation is on the next page

\footnotetext{
${ }^{9}$ Pesantren is Islamic boarding schools, and the traditional educational institutions that educate students by living together and studying in the dormitories, under the guidance of the teacher called the Kyai. Students at the pesantren are called Santri. They live in a complex that provides a mosque for worship, space for learning, and other religious activities. This complex arrangement is such that it is easy to supervise the entry and exit of students according to applicable regulations.
} 


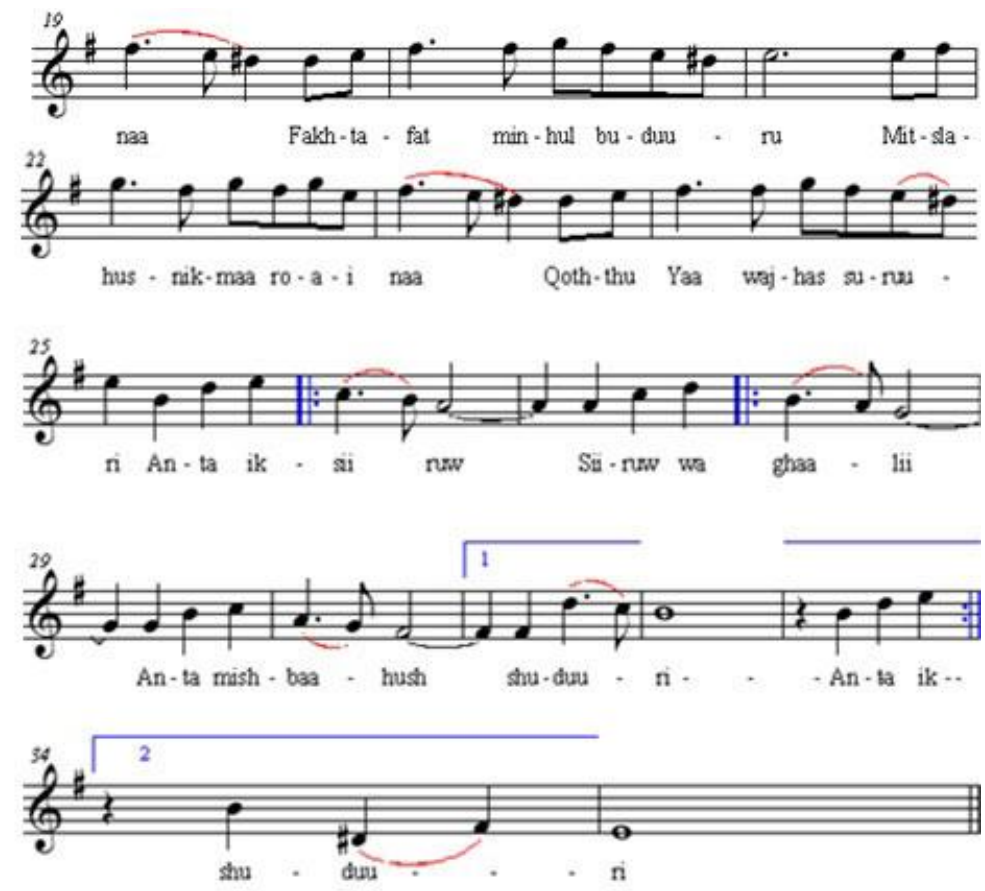

Fig. 18. Notation Ya Nabi Salam an Adaptation of the Song of Cinta Tak Terpisahkan

\section{Conclusion}

Adaptation is a manifestation of high awareness to meet the expectations and demands of the situation and the actual conditions. Adjustment is just a method for finding comfort in social relationships. Campursari music is an organism that serves as a means of carrying out social interaction for the sake of comfortability. Musical adaptation to help the rituals of walimahan, sunatan, and aqiqoh is a strategy of gaining great sympathy in communities that are strong in favor of divine potential. Adaptation among Campursari musicians gave birth to musical syncretism so that (1) pambagiharjo remained Javanese, (2) speeches were strongly impressed with Javanese flavor, (3) the rituals of walimahan, sunatan, and aqiqoh felt a strong sense of Islam, and (4) entertainment gave birth musical colors that satisfy the community of older adults and young people. The performance of campursari is enough to prove that the musicality of campursari music in the context of Islamic rituals is productive syncretism. Therefore, adaptation and syncretism are methods and means of building products, which both must co-exist.

\section{References}

[1] J. Wallach and E. Clinton, "History, Modernity, and Music Genre in Indonesia: Popular Music Genres in the Dutch East Indies and Following Independence," Asian Music, vol. 44, no. 2, pp. 3-23, 2013, DOI: 10.1353/amu.2013.0020.

[2] P. Yampolsky, "Three Genres of Indonesian Popular Music: Genre, Hybridity, and Globalization, 19602012," Asian Music, vol. 44, no. 2, pp. 24-80, 2013, DOI: 10.1353/amu.2013.0018.

[3] Skelchy, "Voice, Age, and Islamic Practice in the Life of the Indonesian Keroncong Vocalist Waldjinah," Ethnomusicology, vol. 63, no. 3, p. 445, 2019, DOI: 10.5406/ethnomusicology.63.3.0445.

[4] M. Perlman, "The Traditional Javanese Performing Arts in the Twilight of the New Order: Two Letters from Solo," Indonesia, vol. 68, p. 1, Oct. 1999, DOI: 10.2307/3351295.

[5] P. Yampolsky, "Javanese Gamelan and the West by Sumarsam," Asian Music, vol. 49, no. 2, pp. 158-162, 2018, doi: 10.1353/amu.2018.0019.

[6] M. Rudiana, "Sundanese Karawitan and Modernity," Panggung, vol. 27, no. 3, Nov. 2017, doi: 10.26742/panggung.v27i3.278. 
[7] N. I. Cooper, "Retuning Javanese Identities: The Ironies of a Popular Genre," Asian Music, vol. 46, no. 2, pp. 55-88, 2015, DOI: 10.1353/amu.2015.0016.

[8] R. Hirschheim and M. Newman, "Symbolism and Information Systems Development: Myth, Metaphor, and Magic,” Inf. Syst. Res., vol. 2, no. 1, pp. 29-62, Mar. 1991, DOI: 10.1287/isre.2.1.29.

[9] S. M. Fabrizio and J. T. Neill, "Cultural adaptation in outdoor programming," J. Outdoor Environ. Educ., vol. 9, no. 2, pp. 44-56, Oct. 2005, DOI: 10.1007/BF03400820.

[10]K. S. McFerran et al., "Music, Rhythm and Trauma: A Critical Interpretive Synthesis of Research Literature," Front. Psychol., vol. 11, Feb. 2020, DOI: 10.3389/fpsyg.2020.00324.

[11]L. Bresler, "Basic and Applied Qualitative Research in Music Education," Res. Stud. Music Educ., vol. 6, no. 1, pp. 5-17, Jun. 1996, DOI: 10.1177/1321103X9600600102.

[12] A. Prasad, "The Contest Over Meaning: Hermeneutics as an Interpretive Methodology for Understanding Texts,” Organ. Res. Methods, vol. 5, no. 1, pp. 12-33, Jan. 2002, DOI: 10.1177/1094428102051003.

[13] A. Edelmann and J. W. Mohr, "Formal studies of culture: Issues, challenges, and current trends," Poetics, vol. 68, pp. 1-9, Jun. 2018, DOI: 10.1016/j.poetic.2018.05.003.

[14]C. Noy, "Sampling Knowledge: The Hermeneutics of Snowball Sampling in Qualitative Research," Int. J. Soc., Res. Methodol., vol. 11, no. 4, pp. 327-344, Oct. 2008, DOI: 10.1080/13645570701401305.

[15]E. K. Silverman, “Anthropology and Circumcision,” Annu. Rev. Anthropol., vol. 33, no. 1, pp. 419-445, Oct. 2004, DOI: 10.1146/annurev.anthro.33.070203.143706.

[16]M. R. Woodward, “The 'Slametan': Textual Knowledge and Ritual Performance in Central Javanese Islam,” Hist. Relig., vol. 28, no. 1, pp. 54-89, Aug. 1988, DOI: 10.1086/463136.

[17]A. Mukholik, "The Variation of the Quran Reception 21st Century in Central Java Indonesia," IJASOSInt. E-journal Adv. Soc. Sci., vol. 3, no. 7, pp. 268-268, Apr. 2017, DOI: 10.18769/ijasos.309686.

[18]E. Fausta, "Sari Oneng Parakansalak Gamelan Tuning System and Its Comparison with Machjar's Theory," Int. J. Vis. Perform. Arts, vol. 1, no. 1, pp. 15-26, Jun. 2019, DOI: 10.31763/viperarts.v1i1.6.

[19]L. Fogelin, “The Archaeology of Religious Ritual,” Annu. Rev. Anthropol., vol. 36, no. 1, pp. 55-71, Sep. 2007, DOI: 10.1146/annurev.anthro.36.081406.094425.

[20] Sumarsam, "Inner Melody in Javanese Gamelan Music," Asian Music, vol. 7, no. 1, p. 3, 1975, doi: $10.2307 / 833922$.

[21]D. Mack, Y. U. Everett, and F. Lau, "Locating East Asia in Western Art Music," Lied und Popul. Kult. / Song Pop. Cult., vol. 48, p. 339, 2003, DOI: 10.2307/4147858.

[22]H. Tachibana, T. Ono, N. Ono, and S. Sagayama, "Melody line estimation in homophonic music audio signals based on temporal-variability of melodic source," in 2010 IEEE International Conference on Acoustics, Speech and Signal Processing, 2010, pp. 425-428, DOI: 10.1109/ICASSP.2010.5495764.

[23]F. M. Mashur, "Interpretation and Overinterpretation of Ja'far Ibn Hasan Al-Barzanji's Mawlid AlBarzanji,” J. Hum., vol. 29, no. 3, p. 316, Oct. 2017, DOI: 10.22146/jh.v29i3.29688. 